\title{
GLOBAL CRUDE OIL PRICE AND DOMESTIC FOOD COMMODITY PRICES: EVIDENCE FROM INDONESIA
}

\author{
Harga Minyak Dunia dan Harga Komoditas Pangan Domestik: \\ Kasus dari Indonesia \\ Tiara Kencana Ayu \\ Graduate School of International Cooperation Studies (GSICS), Kobe University, \\ 2-1 Rokkodai-cho, Nada-ku, Kobe 657-8501, Japan \\ Email: tiarakencanaayu@gmail.com
}

Naskah diterima: 12/11/2019; Naskah direvisi: 10/05/2020; Disetujui diterbitkan: 02/06/2020

Dipublikasikan online: 15/07/2020

\begin{abstract}
Abstrak
Penelitian untuk menganalisis hubungan antara harga minyak dunia dan harga komoditi pangan di pasar domestik masih jarang ditemukan. Dengan membuat Model Panel Data dari 34 provinsi di Indonesia pada tahun 2010-2017, penelitian ini bertujuan untuk menginvestigasi pengaruh perubahan harga minyak dunia terhadap beberapa harga komoditi pangan lokal (kedelai, import, kedelai lokal, beras lokal, dan jagung lokal). Hasil penelitian ini mengindikasikan bahwa harga minyak dunia dapat memengaruhi harga pangan lokal di Indonesia melalui tingginya biaya pengiriman pada aktivitas impor. Selain itu, harga komoditi pangan dunia juga terbukti dapat memengaruhi harga seluruh komoditi pangan lokal yang diteliti, yang mengimplikasikan bahwa harga komoditi pangan di Indonesia dipengaruhi oleh kondisi pasar internasional. Hasil penelitian ini memberikan masukan bagi pembuat kebijakan di Indonesia untuk mempertimbangkan perubahan harga minyak dunia dan harga komoditi global dalam menstabilkan harga komoditi lokal di Indonesia, terutama komoditi yang diimpor.
\end{abstract}

Kata Kunci: Harga Minyak Dunia, Harga Komoditi Pangan, Harga Domestik, Impor

\begin{abstract}
Globally, studies examining the nexus between global crude oil prices and food commodity prices in domestic markets are scant. Employing a panel data model of 34 provinces in Indonesia from 2010 - 2017, this study investigates the impact of global crude oil's price change on some local food commodity prices (imported soybean, local soybean, local rice, and local maize). Previous studies found that local food commodity prices in some countries were not affected by global crude oil prices; however, this study, by controlling other factors which could affect local commodity prices, finds different results. This study's findings indicate that global crude oil prices could affect Indonesia's local commodity prices due to higher shipping costs in import activity. In addition, global commodity prices are also proved to affect all commodities examined in this study, which implies that local food commodity prices in Indonesia are influenced by the international market. This study provides input to policymakers in Indonesia to consider the movement of global crude oil prices and global commodity prices in stabilizing local food commodity prices in Indonesia, especially the imported commodities.
\end{abstract}

Keywords: Global Crude Oil Price, Local Food Commodity Prices, Domestic Price, Import JEL Classification: F15, O13, Q11

\section{INTRODUCTION}

commodity prices, mainly 2007-2008,

The dramatic surge of food has drawn researchers' attention. Many 
tried to find factors that potentially affected the food commodity price increase. Initially, the growing economies of emerging countries were suspected of contributing to this issue since they potentially enhanced demand for food commodities (Abbott \& Borot de Battisti, 2011; Baffes \& Dennis, 2013; Hochman et al., 2014). However, since at the same time, the global oil price also jumped significantly, some studies questioned whether the higher oil price led to the food price crises. It can be shown from a report by Mitchell (2008) that price of maize increased $300 \%$, wheat $127 \%$, and rice $170 \%$ from early 2005 until June 2008, while similarly, according to Fowowe (2016), oil price also increased from 2003 and reached a peak in July 2008 , of US $\$ 145$ per barrel. Therefore, economic literature explains the nexus between these two variables considering the possible relationship between energy price and food commodity prices.
Some reasons were believed to cause the linkage between the two variables. Firstly, the higher oil price was thought to enhance biodiesel production that eventually raised the demand and also the price of agricultural commodities as raw material (Headey \& Fan, 2008; Mitchell, 2008; Wright, 2014; Yu et al., 2006; Zilberman et al., 2013). The expansion of biofuel production potentially forces farmers to choose between supplying energy or food that could create food supply scarcity and eventually raise the food price commodities. Secondly, the higher fuel price was argued to directly affect food commodity prices through higher transportation costs and input production costs that finally increased the price of food commodities (Dillon \& Barrett, 2016; Fowowe, 2016; Mitchell, 2008). Lastly, oil prices could influence food commodity prices through other channels such as exchange rates because of the domination of the USD 
(Abbott et al., 2008; Harri et al., 2009). In detail, the depreciating US Dollar causes the rising number of exports, and a decreasing number of imports called exchange rate effects. This condition happens since the commodity prices of other countries becomes cheaper, while commodity prices for US Dollar increases.

Moreover, research investigating the linkage between world crude oil prices and food commodity prices keeps developing in scope and methodology. Regarding the scope, While many previous studies mostly took the global market as their observation (Ghaith \& Awad, 2011; Mitchell, 2008; Nazlioglu, 2011; Nazlioglu \& Soytas, 2012; Zhang et al., 2010; Zilberman et al., 2013), recently, researchers started to analyze the impact of world oil price movement on the trend of food commodity price in domestic markets (Rahim \& Zariyawati, 2011; Dillon \& Barrett, 2016; Fowowe, 2016; Nazlioglu \& Soytas, 2011; Zhang
\& Reed, 2008). Researching domestic markets' scope is important since the price that affects the poor, especially in developing countries, is the local food price, not the global food price. Besides, in less developed countries, the increase in fuel prices is always linked to the increase in the price of goods, including food (James et al., 2008). In addition, according to Fowowe (2016), since every region has different characteristics, the question of whether global crude oil prices might affect local agricultural prices is hard to generalize.

On the other hand, research aimed to investigate the relationship between global oil price and food price had inconclusive results since these studies used different approaches, data, and methodology. In detail, according to Zhang et al. (2010) and Fowowe (2016), the results of research on this issue can vary due to different assumptions of how oil prices can be related to food commodity prices. In general, there 
were three different approaches that were taken by researchers to examine the nexus between global oil price and food commodity prices: (i) some studies used linear long-run and short-run models; (ii) some studies which assumed non-linear relationship between oil and food commodity prices used non-linear models; and (iii) some studies that took into account other factors that potentially could influence food commodity prices.

Some studies that used long-run and short-run linear models to examine relationships between oil price and food prices assume that the triggers which could influence the food prices in the long-run are different from those in the short-run (Zhang et al., 2010). However, many studies, which used linear causality model, both in long-run and short-run, found that the relationship between oil price and food prices was neutral both in the global and domestic market (Campiche et al., 2007; Ghaith \&
Awad, 2011; Nazlioglu \& Soytas, 2011; Yu et al., 2006; Zhang \& Reed, 2008; Zhang et al., 2010; Zilberman et al., 2013). For example, Yu et al. (2006) concluded that from 1999 until 2006, edible oil prices, including soybean, were not significantly influenced by the change in crude oil prices in global market.

On the other hand, in the domestic market, Zhang \& Reed (2008) researched the rocketing price of pork as a staple food in China. The increasing price of some agriculture commodities, such as animal feed for pigs, was believed to be a trigger of increasing pork prices. In addition, the authors also noticed a higher price of corn and soybean as inputs for biofuel production. Therefore, their research aimed to answer whether the oil price had an impact on the rise of corn, soy meal, and pork. This study also found that higher oil price was not the main factor of higher pork price. Demand and supply 
factors were a trigger for pork prices increasing. In addition, Nazlioglu \& Soytas (2011) also conducted long-run and short-run models to examine the linkage between global crude oil prices and agriculture commodity prices in Turkey. However, in contrast to Zhang \& Reed (2008), Nazlioglu \& Soytas (2011) emphasized that the possible relationship between energy price and agriculture price in Turkey, as an emerging country, is not only a direct relationship through higher input production but also an indirect relationship through the exchange rate. Similarly, this study found a neutrality relationship by concluding that appreciation of the USD and higher global oil price did not drive the change of agricultural prices (wheat, maize, cotton, soybean, and sunflower) in Turkey.

Secondly, the methodology of this issue kept developing, and some started to hypothesize that there was likely a nonlinear relationship between oil price and food commodity prices. According to Fowowe (2016), an ordinary linear causality test could be biased if the data of both oil price and food commodity prices have structural breaks or nonlinear trend. However, the result of research which considered nonlinear relationship was inconclusive. For example, after getting the neutrality result in his previous study in Turkey, Nazlioglu (2011) continued research the nexus between global oil price and global agriculture commodity prices by exploring both linear and nonlinear causality method. His idea about the possibility of a nonlinear trend came from the fact that, since the financial crisis in 2007-2008, the trend of oil price and agricultural prices has become much higher than historical data. In addition, he also argued that the government initiated policy changes possibly became a factor of the nonlinear trend. As a result, the linear 
causality analysis showed that the change of oil price did not transmit to the change in agriculture prices (corn, soybean, and wheat). However, nonlinear causality analysis showed that oil price and corn, as well as soybean, had nonlinear causality. To sum up, this research implied that a nonlinear model gave better clues in explaining the relationship between oil price and agricultural prices.

Moreover, considering the presence of structural breaks, as presented by Nazlioglu (2011) above, Fowowe (2016) also exploited a nonlinear causality model to investigate the relationship between global oil price and agriculture commodity price in South Africa, which also experienced a price surge from 2007 until 2014. In his paper, he stated that studies that use a linear model and do not divide the period of data, to anticipate structural breaks, would likely find a neutrality relationship between oil price and agriculture commodity prices. Therefore, he decided to use a nonlinear model by employing Gregory and Hansen 's cointegration technique, which takes into account structural breaks. Similar to Nazlioglu (2011), Fowowe (2016) also used the Diks and Pachenko procedure for nonlinear causality tests. Nevertheless, unlike Nazlioglu (2011), the result of this study did not prove the relationship between global oil price and agriculture commodity prices in South Africa. The different results between this study and Nazlioglu (2011) might be caused by the difference in data sets between these studies, where Nazlioglu (2011) researched global market data, while Fowowe (2016) examined the relationship between global crude oil price and domestic food prices in South Africa.

Lastly, several studies that considered some other factors in examining the relationship between oil price and food commodity prices. 
Researchers argued that the movement of food prices is affected by many triggers both from the demand and supply side. Therefore, including these other factors was supposed to give a more precise result when examining the relationship between global crude oil price and food commodity prices since it can avoid omitted variable bias. For example, one of the factors that were commonly included into the model between energy price and food prices was exchange rate, since global commodity prices, including oil prices, are dominated by USD (Baffes \& Dennis, 2013; Dillon \& Barrett, 2016; Nazlioglu \& Soytas, 2011, 2012). Intuitively, a depreciating USD could attract exports of commodities and reduce imports since the price of commodities in other countries becomes cheaper, but the price of commodities in the US increases (Harri et al., 2009).

Other factors that were considered to affect food prices, especially in local markets, were local fuel prices and global food commodity prices. For example, research was conducted by Dillon \& Barrett (2016) that tried to answer whether maize prices in East Africa related to global oil prices. Unlike other studies, this paper explored some channels which cause the price of food commodity to be affected by the higher global oil price. The primary mechanisms that were concluded the domestic market's food price were transportation cost and transmission from the global commodity prices. Firstly, since East Africa is quite far away from the exporting countries, and within East Africa distribution activity still depends on trucks, there was a possibility that maize prices in East Africa was affected by the rise of global oil prices through transportation cost. Secondly, Dillon \& Barrett (2016) also suggested that global oil prices could influence local food prices through price transmission of global commodity prices. They 
considered the results of some studies which conclude a significant relationship between global oil price and global food price (Abbott et al., 2008; Mitchell, 2008; Wright, 2014), and also the work of Benson et al. (2008), Baffes \& Gardner (2003), and Minot (2011), about transmission from global food prices to domestic food prices. Therefore, Dillon \& Barrett (2016) included global commodity price and local fuel price in measuring the effect of global crude oil price on maize price in East Africa. The results found that the maize price in East Africa was significantly affected by global oil prices through both mechanisms. In detail, using the stepwise error correction model, they found that the transmission, due to transport costs, was faster than transmission from global commodity price. In contrast, they stated that the growth of biofuel production and the higher cost of non-organic fertilizer produced from fossil fuel were less significant in influencing food commodity prices in domestic markets.

Moreover, Baffes \& Dennis (2013) researched to investigate the determinants of some global food commodity prices. In their study, they considered some other determinants of food prices: demand side, supply side, and macro variables such as Gross Domestic Product (GDP) and interest rate. GDP was considered to affect the food prices since it could represent the income of a country. Similarly, Nugraheni (2014) and Ahsan et al. (2011) who investigated food prices determinant in Indonesia and Pakistan respectively also considered income to affect local food price. These studies included GDP per capita to measure people's standard of living in a region.

This research aims to analyze the relationship between food commodity prices in Indonesia and global crude oil prices. Indonesia has unique characteristics that enable food prices in 
this country to be affected by the higher global oil price. Firstly, Indonesia is both an oil exporter and an importer, producing and exporting raw oil (Setyawan, 2014). However, since the production of processed oil cannot fulfill the domestic need, Indonesia is forced to import processed fuel. Moreover, Setyawan (2014) also found that the hike in fuel price potentially creates ruinous effects on the transportation sector. He suggested that those sectors which are hugely affected by higher fuel price should get special attention from the government regarding rocketing prices. For example, the increase in transportation costs causes a hike in food prices because of higher distribution costs from producer to consumer.

Although Indonesia largely produces food commodities such as soybean, maize, and rice, it still imports these commodities to maintain stock. As shown in Table A.1 Appendix A, the percentage of imported soybean was more than $65 \%$ from 2010 - 2015 compared to total consumption. Besides, Indonesia also still imports maize to fulfill the nation's consumption, around $14 \%$ in 2013 - 2015. Therefore, this condition will make it reasonable for food commodity prices in Indonesia to be driven by world oil prices due to higher shipping costs as described by Mitchell (2008), Minot (2011), and Dillon \& Barrett (2016).

However, the above narrative does not imply that the significant effect of global oil price movement on food prices in Indonesia is visible. According to Baffes \& Gardner (2003), the government in a less developed country will try to protect the domestic market from the high prices in the global market. For example, through the Ministry of Trade, Indonesian Government has an obligation to stabilize some primary needs, including staple food (Republic of Indonesia, 2020). In addition, Indonesia still partially implements fuel 
subsidies to mitigate the direct effect of higher oil prices. Therefore, this study will examine whether Indonesia's food commodity prices (imported soybean, local soybean, local rice, local maize) are still affected by the change of global oil price despite the partial fuel subsidy that is implemented in Indonesia.

There are few research investigations on the effect of global crude oil prices on local food commodity prices. This study will contribute to the current empirical literature. In addition, studies that used sub-national data on this issue are quite rare. Therefore, this study will increase knowledge regarding the relationship between the global oil price and local food commodity prices.

This research is organized as follows: The second part is methodology and data, which describes the empirical strategy in addressing the aim of this result; The third part is empirical results; the Conclusion and Policy implications are presented in the last part.

\section{RESEARCH METHODS}

\section{Empirical Methodology}

This study employs Panel Data Method to examine the impact of global crude oil price change towards four local food commodity prices in Indonesia, imported soybean, local soybean, local rice, and local maize. The panel Data Method is acknowledged as more potent since it combines information from both the cross-section and time component (Nazlioglu \& Soytas, 2012). This method will be an advantage of this study since most of the previous study applied time series analysis. This also study includes more variables to give more precise results in investigating the relationship between global oil prices and local food prices since more variables can control the effect of other factors on local food prices. Two independent variables are a lagging variable of global crude oil price and global food price to allow a dynamic effect on local food commodity prices. This study is conducted on a data set of 
34 provinces in Indonesia from 2010 2017. However, due to data availability, the structure of data is an unbalanced panel (Wooldridge, 2015). Since the period of data is relatively short, we do not control possible structural break. Thus, the equation of panel data is as follows:

$$
\begin{aligned}
& L P_{i t}=\beta_{o}+\beta_{1} O P_{t}+\beta_{2} G P_{t}+\beta_{3} G D P C_{i t}+\beta_{4} E X_{t}+\beta_{5} I R_{t}+\beta_{6} O P_{t-1}+\beta_{7} G P_{t-1}+ \\
& a_{i}+\varepsilon_{i t}
\end{aligned}
$$

Where $i$ refers to the province and $t$ refers to the quarterly time period from $2010-2017 ; \quad L P_{i t}$ is the natural logarithm of local commodity prices, $O P_{t}$ is the natural logarithm of global crude oil price, $G P_{t}$ is the natural logarithm of global commodity price, $G D P C_{i t}$ is the natural logarithm of GDP per capita, $E X_{t}$ is the exchange rate of IDR to USD, $I R_{t}$ is the Indonesia policy rate in period $\mathrm{t}, O P_{t-1}$ is the natural logarithm of global oil price at time $\mathrm{t}-1$, and $G P_{t-1}$ is the natural logarithm of global oil price at time $\mathrm{t}-1$. As shown in the model, natural logarithm of GDP per capita becomes the only variable that shows the uniqueness of each province.

In examining the effect of global crude oil price on local food commodity price, some independent variables are considered in the model to avoid omitted variable biased (Wooldridge, 2015), since there could be some factors which possibly influence local food commodity price in Indonesia. In detail, the expected relation of the dependent variable and other independent variables can be explained as below:

a. Global Commodity Price

Some studies argued that the change of commodity price in the global market could be transmitted to the local market, especially when the country imports the commodity (Benson, Mugarura, \& Wanda, 2008, Varela \& Taniguchi, 2014). 
Specifically, Nugraheni (2014) argued that although a country does not import commodities from other countries, the local price is still influenced by the higher global food price. Therefore, it is expected that there will be a positive relationship between Indonesia's food price and global food price.

b. Region GDP per Capita GDP per capita, the proxy of income, shows the power purchasing of people. Proxy of income was important as higher-income can lead to higher demand for food that eventually will also increase the prices. Therefore, it is expected that GDP Percapita also positively relates to local food prices.

c. Exchange Rate

As explained in a previous chapter, when Rupiah is appreciated, the price of import goods seems cheaper. This phenomenon causes a higher supply due to higher import volume and leads to lower prices in Indonesia. Therefore, since the decreasing value of exchange rate data shows Rupiah's appreciation, this research also expects a positive relationship between exchange rate and local price.

\section{d. Interest Rate}

The fluctuation of interest rate is usually seen to determine economic conditions. According to Baffes \& Dennis (2013), the interpretation of interest rate in influencing food prices was ambiguous. On the one hand, the relationship could be negative since higher interest rate leads to lower commodity price due to lower commodity demand. On the other hand, the interest rate could relate to higher commodity prices due to the higher cost of storage.

As mentioned before, four food commodities are examined in this study: imported soybean, local soybean, local rice as the staple food of Indonesia, and 
local maize. The data for each commodity is provincial-level data in which, due to data availability, the number of provinces is different for each commodity. Furthermore, in examining the effect of global oil price changes on local commodity prices, this study also includes some control variables that may affect local food prices in Indonesia. In detail, these variables represent the supply side, demand side, and macro economy effects such as global commodity prices, GDP per capita, interest rate, and exchange rate.

Firstly, according to Dillon \& Barrett (2016), the local food prices used in this study are consumer prices of imported soybean, local soybean, local rice, and local maize in every capital city of provinces in Indonesia. The survey of local commodity prices was done by the Indonesia Ministry of Trade; however, the author retrieved the data from the Ministry of Agriculture of Indonesia.
Every local food commodity price is measured in Indonesian Rupiah/kg (IDR/kg). Secondly, the global oil price is an independent variable that becomes the main interest of the study. Similar to some studies (Dillon \& Barrett, 2016; Fowowe, 2016; Nazlioglu \& Soytas, 2011), we use crude oil price data averaged from three spots: Brent, Dubai, and West Texas Intermediate (WTI). This data is in US\$/barrel (USD/bbl) and retrieved from The Pink Sheet World Bank. Also, we add the first lag of global oil prices in the model since price adjustment possibly does not occur immediately (Abbott \& Borot de Battisti, 2011; Huh \& Park, 2013). For global commodity prices, we use the rice price of Thailand, soybean spot price in Rotterdam and maize price of US Gulf Ports. All global food commodity prices are measured in USD/metric ton (USD/mt) and derived from The Pink Sheet World Bank Commodity Price Data. Similar to the global oil prices, the 
first lag of global commodity prices is also included in the model.

This study also includes an exchange rate variable, which is defined as the value of USD in Rupiah (IDR). In detail, the increasing value of exchange rate data shows the depreciation of Rupiah or appreciation of USD. We use the exchange rate data of IDR to USD from Reuters. Lastly, this study also considers the national interest rate as a variable that can influence local food prices in Indonesia. The proxy of interest rate that is used is the policy rate. This data is retrieved from the website of the Central Bank in Indonesia (Bank of Indonesia).

\section{EMPIRICAL RESULTS}

This study estimates the impact of global crude oil prices on four local commodity prices in Indonesia: imported soybean, local soybean, local rice, and local maize. As a result, the commodities react differently to the change of global crude oil prices. In addition, the factors which influence each local commodity price are different. Table 1 presents the results of the imported soybean model. The estimation results of panel data, both for the Fixed Effects Model (FEM) and Random Effects Model (REM), show that imported soybean in Indonesia is positively affected by the change of global crude oil price currently and in the past. In detail, from the results we can deduce that if global crude oil price increases by $1 \%$, the immediate increase in imported soybean price are $0.0813 \%$. Meanwhile, after two periods of time (6 months), if global crude oil price increases by $1 \%$, imported soybean price will increase by $0.1174 \%$ even after other variables are controlled. 
Table 1. Regression Results of Imported Soybean

\begin{tabular}{lcc}
\hline \multicolumn{2}{c}{ Dependent Variable : Natural Logarithm of Imported Soybean Price } \\
Independent Variables & FEM & REM \\
\hline Ln Global Crude Oil Price & $0.0813^{* * *}$ & $0.0812^{* * *}$ \\
& $(0.0192)$ & $(0.0193)$ \\
Ln Global Soybean Price & $-0.0880^{* *}$ & $-0.0884^{* *}$ \\
Exchange Rate & $(0.0390)$ & $(0.0391)$ \\
& $0.0606^{* * *}$ & $0.0601^{* * *}$ \\
Ln GDP per capita & $(0.0074)$ & $(0.0074)$ \\
& 0.0393 & 0.0490 \\
Interest Rate & $(0.0699)$ & $(0.0452)$ \\
& $0.0330^{* * *}$ & $0.0332^{* * *}$ \\
Ln Lag Global Crude Oil Price & $(0.0060)$ & $(0.0059)$ \\
& $0.0362^{*}$ & $0.0362^{*}$ \\
Ln Lag Global Soybean Price & $(0.0197)$ & $(0.0197)$ \\
& $0.157^{* *}$ & $0.156^{* *}$ \\
Constant & $(0.0644)$ & $(0.0638)$ \\
& $6.791^{* * *}$ & $6.655^{* * *}$ \\
Observations & $(1.018)$ & $(0.678)$ \\
R-squared (overall) & 783 & 783 \\
Number of Provinces & 0.4024 & 0.4074 \\
Hausman p-value & 29 & 29 \\
\hline
\end{tabular}

Notes : (a) Robust standard errors in parentheses. (b) ${ }^{* * *},{ }^{* *}$, and * denote statistical significance at $1 \%, 5 \%$, and $10 \%$ respectively. (c) Year dummies are included in both models.

This result is in line with Dillon \& imported soybean prices could be Barrett's (2016) findings, which show caused by the higher shipping cost in that global crude oil prices could affect import activity from exporter maize prices in East Africa after countries. Dillon \& Barrett (2016) controlling the effect of global maize supported this possible explanation, price and exchange rate. Regarding the which found that the effect of global relatively high import volume of imported crude oil's price change is more soybean in Indonesia, the significant significant in Kenya than other regions in effect of global crude oil prices on East Africa since Kenya is a region that 
imports maize in the most significant number.

In addition, the price of imported soybean is also significantly affected by the change of global soybean price where, after six months, if global soybean price increases by $1 \%$, imported soybean price will increase by $0.069 \%$. This result is reasonable since the share of imported soybean in Indonesia's market is high, implying that the price is highly related to the global market. Also, $95 \%$ of the import volume of soybean to Indonesia in $2010-2017$ came from the United States, and the US soybean is used as the global price point (Trade Map, 2019). Lastly, the exchange rate and policy rate are also proven to influence the change of imported soybean prices significantly, which means that the two variables are essential inclusions in the model to avoid variable omitted biased (Wooldridge, 2015).
In contrast, as presented in Table 2 and Table 3, local soybean prices and local rice prices are not significantly affected by the change of global crude oil price. Local soybean price in Indonesia is affected by lag soybean price in the international market. Meanwhile, rice price in Indonesia is influenced by global rice price where, after six months, if global rice price increases $1 \%$, local rice price will increase by $0.547 \%$. This means, although local soybean and local rice are not affected by the change of global oil price, both commodities are still affected by the international market. According to Fowowe (2016), the neutral relationship between global oil price and local commodity prices is reasonable since global oil price is pinned to the global market, while local commodity price is formed in the local market. In other words, local soybean prices and local rice prices might be influenced more by demand and supply factors, 
such as weather, stocks, or the people in Indonesia, and the government's policy to create price government monitors its price to ensure stabilization. Rice is the staple food for stability.

Table 2. Regression Results of Local Soybean

\begin{tabular}{lcc}
\hline \multicolumn{2}{c}{ Dependent Variable : Natural Logarithm of Local Soybean Price } \\
Independent Variables & FEM & REM \\
\hline Ln Global Crude Oil Price & 0.0219 & 0.0236 \\
& $(0.0365)$ & $(0.0363)$ \\
Ln Global Soybean Price & 0.0125 & 0.0079 \\
& $(0.0619)$ & $(0.0630)$ \\
Exchange Rate & $0.0572^{* * *}$ & $0.0562^{* * *}$ \\
& $(0.0104)$ & $(0.0104)$ \\
Ln GDP per capita & -0.0608 & -0.0350 \\
& $(0.0879)$ & $(0.0586)$ \\
Interest Rate & $0.0178^{*}$ & $0.0188^{*}$ \\
Ln Lag Global Crude Oil Price & $(0.0098)$ & $(0.0099)$ \\
& 0.0415 & 0.0397 \\
Ln Lag Global Soybean Price & $(0.0282)$ & $(0.0264)$ \\
Constant & $0.140^{* *}$ & $0.140^{* *}$ \\
Observations & $(0.0597)$ & $(0.0604)$ \\
R-squared (overall) & $7.375^{* * *}$ & $7.362^{* * *}$ \\
Hamber of Provinces & $(0.263)$ & $(0.259)$ \\
\hline
\end{tabular}

Notes : (a) Robust standard errors in parentheses. (b) ${ }^{* * *},{ }^{* *}$, and * denote statistical significance at $1 \%, 5 \%$, and $10 \%$ respectively. (c) Year dummies are included in both models. 
Table 3. Regression Results of Local Rice

\begin{tabular}{lcc}
\hline \multicolumn{2}{c}{ Dependent Variable : Natural Logarithm of Local Rice Price } \\
Independent Variables & FEM & REM \\
\hline Ln Global Crude Oil Price & -0.0113 & -0.0122 \\
Ln Global Rice Price & $(0.0164)$ & $(0.0158)$ \\
& $0.312^{* * *}$ & $0.307^{* * *}$ \\
Exchange Rate & $(0.0516)$ & $(0.0511)$ \\
& $0.0802^{* * *}$ & $0.0771^{* * *}$ \\
Ln GDP per capita & $(0.0094)$ & $(0.0088)$ \\
& -0.0131 & $0.0427^{* *}$ \\
Interest Rate & $(0.0336)$ & $(0.0189)$ \\
& 0.0026 & 0.0037 \\
Ln Lag Global Crude Oil Price & $(0.0044)$ & $(0.0043)$ \\
& -0.0006 & -0.0031 \\
Ln Lag Global Rice Price & $(0.0176)$ & $(0.0176)$ \\
Number of Provinces & $0.248^{* * *}$ & $0.240^{* * *}$ \\
Hausman p-value & $(0.0380)$ & $(0.0361)$ \\
\hline
\end{tabular}

Notes : (a) Robust standard errors in parentheses. (b) ${ }^{* * *},{ }^{* *}$, and ${ }^{*}$ denote statistical significance at $1 \%, 5 \%$, and $10 \%$ respectively. (c) Year dummies are included in both models.

Next, Table 4 shows the regression impact on local maize price in the past. results for maize. Although the change This means the impact of global crude of global crude oil price does not oil prices on local maize prices does not currently influence maize prices, the happen instantaneously. Imported global crude oil price has a positive maize was $15 \%$ of total consumption, 
while Indonesia's export values of maize and soybean are minimal (less than $2 \%$ ) (Trade Map, 2019).

Therefore, it is plausible that the import activity also leads to maize prices in Indonesia affected by the change of global oil price. In addition, maize price is also influenced by the lag of global maize price. Considering the explanation of Abbott \& Borot de Battisti (2011), these results imply that similar to other commodities, the maize price in Indonesia is also affected by the change in the international market.

Moreover, the exchange rate also significantly influence all examined local food commodity prices. These results support many studies which argued that one of fundamental factor that drove the change of food commodity price is the exchange rate (Abbott et al., 2008; Abbott et al., 2011; Baffes \& Dennis,
2013; Dillon \& Barrett, 2016; Harri et al., 2009; Nazlioglu \& Soytas, 2011, 2012; Nugraheni, 2014).

Lastly, the Hausman test of panel data models from all commodities indicates that the preferred model is the Random Effects Model. However, the Fixed Effects Model and Random Effects Model have a very close value of the estimated coefficient so that both models can be considered. A quite similar result between the Fixed Effects Model and Random Effects Model indicates that the impact of global oil's price change on local commodity prices in Indonesia is not different among provinces in Indonesia. This means that anticipating the effect of higher global crude oil price and global food commodity prices, the government can implement national policy in all provinces in Indonesia. 
Table 4. Regression Results of Local Maize

Dependent Variable : Natural Logarithm of Maize Price

\begin{tabular}{lcc} 
Independent Variables & FEM & REM \\
\hline Ln Global Crude Oil Price & 0.0208 & 0.0209 \\
Ln Global Maize Price & $(0.0276)$ & $(0.0276)$ \\
Exchange Rate & 0.0508 & 0.0482 \\
& $(0.0496)$ & $(0.0503)$ \\
Ln GDP per capita & $0.0358^{* * *}$ & $0.0328^{* * *}$ \\
& $(0.0109)$ & $(0.0116)$ \\
Interest Rate & $0.0811^{*}$ & $0.119^{* * *}$ \\
& $(0.0453)$ & $(0.0372)$ \\
Ln Lag Global Crude Oil Price & 0.0073 & 0.0089 \\
& $(0.0081)$ & $(0.0080)$ \\
Ln Lag Global Maize Price & $0.0492^{* *}$ & $0.0479^{* *}$ \\
Constant & $(0.0211)$ & $(0.0210)$ \\
& $0.157^{* * *}$ & $0.153^{* * *}$ \\
Observations & $(0.0471)$ & $(0.0476)$ \\
R-squared (overall) & $6.824^{* * *}$ & $6.826^{* * *}$ \\
Number of Provinces & $(0.4740)$ & $(0.4810)$ \\
Hausman p-value & 1,052 & 1,052 \\
\hline
\end{tabular}

Notes : (a) Robust standard errors in parentheses. (b) ${ }^{* * *},{ }^{* *}$, and ${ }^{*}$ denote statistical significance at $1 \%, 5 \%$, and $10 \%$ respectively. (c) Year dummies are included in both models.

CONCLUSION AND POLICY significant impact of global crude oil RECOMMEDATION price change on local food commodity

This study aims to examine the price (Zhang \& Reed, 2008.; Nazlioglu \& impact of global crude oil prices on local Soytas, 2011; Fowowe, 2016), the food prices in Indonesia. While most results of this study are in line with the previous research did not find a result of Dillon \& Barrett (2016) who 
found a significant impact of higher global crude oil price on maize price in East Africa.

In detail, this study finds evidence that imported soybean prices and maize prices in Indonesia are affected by the change of global crude oil prices. The significant impact might happen due to the higher delivery cost of import activities from the exporter country to Indonesia, which eventually contributes an additional price for imported soybean in Indonesia.

However, the main staple food of Indonesia, rice, which only has a small share of imports, is not affected by the change of global crude oil price. This indicates that Indonesia's local food commodities are highly influenced by demand and supply factors within the country. In detail, rice price in Indonesia is carefully monitored by the government since it is fluctuation may affect society's welfare, especially The Poor.
This research contributes to the current empirical literature: 1) it examines the relationship between global crude oil price and some local food commodity prices in Indonesia and finds that import activity might cause global crude oil price to affect local food prices, in contrast to some previous research; 2) while most research employs time series data, this study investigates the relationship between global crude oil price and some local food commodity prices by employing panel data of provinces in Indonesia which gives more information both from cross-section and time component; 3 ) it uses more current data, including data from the oil crisis period in $2011-2013$, and price data of global crude oil price after 2014 when oil price decreased.

The findings suggest the need for further studies. First, a study using more extended time data would allow analysis that considers structural breaks. Second, a study that includes more control 
variables to depict the demand and supply factors within the country, such as stocks, would likely give more reliable results. Thirdly, due to limited access to data and the fact that Indonesia partially implements fuel subsidy, this study does not consider local fuel prices in Indonesia. A study, including local fuel prices would get a better result since the price of global crude oil might affect local food commodity prices through local fuel prices (Dillon \& Barrett, 2016).

The results of this study indicate that Indonesia's food commodity prices tend to be affected by the change of global crude oil prices when Indonesia still depends on importing the commodities. If Indonesia cannot produce commodities, import activity is unavoidable. In addition, if imported soybean prices are lower than local soybean prices, the import volume of soybean in Indonesia will likely stay high. The import dependency could be a severe problem when global crude oil price increases dramatically. Eventually, fuel prices will affect imported food commodities. In fact, as an agricultural country, Indonesia should have the ability to enhance the production of soybean and maize to reduce the value of imports. In short, the findings of this study suggest policymakers in Indonesia should not ignore the fluctuation of global crude oil prices and global food commodity prices in maintaining the stability of local food commodity prices, especially those with high import volume.

On the other hand, the neutral relationship between rice, Indonesia's staple food, and global crude oil price implies that Indonesia's government has already implemented market intervention for rice in Indonesia. When rice experiences a higher price, the government should consider factors within the country and may ignore the fluctuation of global crude oil prices as long as the import volume of rice is small. 
However, if Indonesia imports rice in higher volume in the future, the government should take into account the change of global crude oil price and global rice price.

\section{ACKNOWLEDGEMENT}

The author thanks Professor Koji

Kawabata, Professor Masahiro Kodama, and Dr. Arie Damayanti for excellent assistance as an academic supervisor at Kobe University and Universitas Indonesia. The author would also thank the National Development Agency of Indonesia (BAPPENAS) and my institutions, Ministry of Trade, for giving me an invaluable chance to pursue a master's degree through the linkage program.

\section{REFERENCES}

Abbott, P., \& Borot de Battisti, A. (2011). Recent Global Food Price Shocks: Causes, Consequences and Lessons for African Governments and Donors. Journal of African Economies, 20(suppl.1), i12-i62.

Abbott, P. C., Hurt, C, \& Tyner, W. E. (2008). What's Driving Food Prices? (Issue Report July 2008). Oak Brook, IL: Farm Foundation.

Abbott, P. C., Hurt, C, \& Tyner, W. E. (2011). What's Driving Food Prices? (Issue
Report July 2011). Oak Brook, IL: Farm Foundation.

Ahsan, H., Iftikhar, Z., \& Kemal, M. A. (2011). The Determinants of Food Prices: $A$ Case Study of Pakistan (PIDE Working Papers). Islamabad, Pakistan: Pakistan Institute of Development Economics.

Baffes, J., \& Gardner, B. (2003). The Transmission of World Commodity Prices to Domestic Markets under Policy Reforms in Developing Countries. The Journal of Policy Reform, 6(3), 159-180.

Baffes, J., \& Dennis, A. (2013). Long-Term Drivers of Food Prices (Working Paper 6455, May 2013). Washington, D. C.: The World Bank.

Benson, T., Mugarura, S., \& Wanda, K. (2008). Impacts in Uganda of Rising Global Food Prices: The Role of Diversified Staples and Limited Price Transmission. Agricultural Economics, 39 (Supple. 1), 513-524.

Campiche, J.L., Bryant, H.L., Richardson, J.W., Outlaw, J.L., (2007, July August). Examining the Evolving Correspondence Between Petroleum Prices and Agricultural Commodity Prices. Paper presented at American Agricultural Economics Association Annual Meeting, Portland, Oregon.

Dillon, B. M., \& Barrett, C. B. (2016). Global Oil Prices and Local Food Prices: Evidence from East Africa. American Journal of Agricultural Economics, 98(1), 154-171.

Fowowe, B. (2016). Do oil prices drive agricultural commodity prices? Evidence from South Africa. Energy, 104, 149-157.

Ghaith, Z., \& Awad, I. M. (2011). Examining the Long Term Relationship Between Crude Oil and Food Commodity Prices: Co-integration and Causality. International Journal of Economics and Management Sciences, 1(5), 6272.

Harri, A., Nalley, L., \& Hudson, D. (2009). The Relationship between Oil, Exchange Rates, and Commodity 
Prices. Journal of Agricultural and Applied Economics, 41(2), 501-510.

Headey, D., \& Fan, S. (2008). Anatomy of a Crisis: The Causes and Consequences of Surging Food Prices. Agricultural Economics, 39(3), 37-391.

Hochman, G., Rajagopal, D., Timilsina, G., \& Zilberman, D. (2014). Quantifying the Causes of the Global Food Commodity Price Crisis. Biomass and Bioenergy, 68, 106-114.

Huh, H. S., \& Park, C. Y. (2013). Examining the Determinants of Food Prices in Developing Asia (Working Series Paper no. 370, September 2013). Phillippines: Asian Development Bank.

James, W. E. et al. (2008). Food Prices and Inflation in Developing Asia: Is Poverty Reduction Coming to an End? (Special Report, April 2008). Phillippines: Asian Development Bank.

Minot, N. W. (2011). Transmission of World Food Price Changes to Markets in Sub-Saharan Africa (Discussion Paper 01059, Januari 2011). Washington, DC.: International Food Policy Research Institute.

Mitchell, D. (2008). A Note on Rising Food Prices (Working Paper 4682, July 2008). Washington, D. C.: The World Bank.

Nazlioglu, S. (2011). World oil and agricultural commodity prices: Evidence from nonlinear causality. Energy Policy, 39(5), 2935-2943.

Nazlioglu, S \& Soytas, U. (2011). World oil prices and agricultural commodity prices: evidence from an emerging market. Energy Economics, 33, 488 496.

Nazlioglu, S., \& Soytas, U. (2012). Oil price, agricultural commodity prices, and the dollar: A panel cointegration and causality analysis. Energy Economics, 34(4), 1098-1104.

Nugraheni, S. R. W. (2014). The Staple Food Prices Volatility in Indonesia and Its Influencing Factors (Master Thesis,
IPB University, 2014).

Rahim, A., \& Zariyawati, M. A. (2011). Causal Effects of World Crude Oil Prices on the Prices of Rice and Soybean Oil: An ARDL Approach. Pertanika Journal of Social Science and Humanities, 19(1), 123-130.

Republic of Indonesia. (2020). Peraturan Presiden Republik Indonesia Nomor 59 Tahun 2020 tentang Perubahan atas Peraturan Presiden nomor 71 Tahun 2015 Tentang Penetapan dan Penyimpanan Barang Kebutuhan Pokok dan Barang Penting.

Setyawan, D. (2014). The Impacts of the Domestic Fuel Increases on Prices of the Indonesian Economic Sectors. Energy Procedia, 47, 47-55.

Trade Map. (2019). Trade Map Statistics. Accessed in 2019 from trademap.org

Varela, G. J., \& Taniguchi, K. (2014). Asymmetric Price Transmission in Indonesia's Wheat Flour Market (Working Paper 394, March 2014). Phillippines: Asian Development Bank.

Wooldridge, J. M. (2015). Introductory Econometrics: A Modern Approach (6th ed.). Boston, USA: Cengage Learning.

Wright, B. (2014). Global Biofuels: Key to the Puzzle of Grain Market Behavior. Journal of Economic Perspectives, 28(1), 73-98.

Yu, T. -H. E., Bessler, D.A., Fuller, S. (2006, May). Cointegration and Causality Analysis of World Vegetable Oil and Crude Oil Prices. Paper presented at American Agricultural Economics Association Annual Meeting, Long Beach, California.

Zhang, Q., \& Reed, M. (2008, February). Examining the Impact of the World Crude Oil Price on China's Agricultural Commodity Prices: The Case of Corn, Soybean, and Pork. Paper presented at the Southern Agricultural Economics Association Annual Meetings, Dallas, Texas.

Zhang, Z., Lohr, L., Escalante, C., \& Wetzstein, M. (2010). Food versus 
fuel: What do Prices Tell Us? Energy Policy, 38(1), 445-451.

Zilberman, D., Hochman, G., Rajagopal, D., Sexton, S., \& Timilsina, G. (2013). The
Impact of Biofuels on Commodity Food Prices: Assessment of Findings. American Journal of Agricultural Economics, 95(2), 275-281. 
